\title{
Notes on the distribution of an alien weed Hyptis brevipes (Lamiaceae) in India
}

\author{
Rohit K. Verma1 ${ }^{\star}$, Bilal A. Khan¹, Vijay V. Wagh¹, Baleshwar Meena ${ }^{1}$, Soumit K. Behera, Sushma Tamta² \& Lal B. \\ Chaudhary ${ }^{1}$
}

${ }^{1}$ P.D.S.H. Division, CSIR-National Botanical Research Institute, Rana Pratap Marg, Lucknow- 226 001, Uttar Pradesh, India

${ }^{2}$ Department of Botany, Kumaun University, Nainital- 263001 , Uttarakhand, India

^Email: rohityash.verma2@gmail.com

OPEN ACCESS

\section{ARTICLE HISTORY}

Received: 30 July 2021

Accepted: 28 December 2021

Available online

Version 1.0: 20 February 2022

Check for updates

\section{Additional information}

Peer review: Publisher thanks Sectional Editor and the other anonymous reviewers for their contribution to the peer review of this work.

Reprints \& permissions information is available at https://horizonepublishing.com/ journals/index.php/PST/open_access_policy

Publisher's Note: Horizon e-Publishing Group remains neutral with regard to jurisdictional claims in published maps and institutional affiliations.

Indexing: Plant Science Today, published by Horizon e-Publishing Group, is covered by Scopus, Web of Science, BIOSIS Previews, Clarivate Analytics, etc. See https://

horizonepublishing.com/journals/index.php/ PST/indexing_abstracting

Copyright: () The Author(s). This is an openaccess article distributed under the terms of the Creative Commons Attribution License, which permits unrestricted use, distribution and reproduction in any medium, provided the original author and source are credited (https://creativecommons.org/licenses/ by/4.0/)

\section{CITE THIS ARTICLE}

Verma R K, Khan B A, Wagh V V, Meena B, Behera S K, Tamta S, Chaudhary L B. Notes on the distribution of an alien weed Hyptis brevipes (Lamiaceae) in India. Plant Science Today. 2022;9(sp1):1-4.

https://doi.org/10.14719/pst.1421

\begin{abstract}
Hyptis brevipes Poit. is a native weed species of South and Central America and has been introduced and naturalized in many parts of SE Asia. It was reported from India for the first time in 1940 from Andaman and Nicobar Islands and then in 2012 from Darjeeling Himalaya. In the present study the authors have noticed the occurrence of the species in the wild in the Dima Hasao district of Assam and the Dampa Tiger Reserve of Mizoram. The study reveals that the species has naturalized in India in some parts of the Northeast region in cultivated lands along roadsides. The detailed taxonomic account of the species along with its distribution, phenology, uses and photographs is provided to confirm its identity and to take stock on its control from its further spread to some other regions, because due to the invasive nature it may affect the growth of crop plants.
\end{abstract}

\section{Keywords \\ Assam, Dima Hasao, Hyptis, New record, NE India}

\section{Introduction}

Hyptis Jacq. is a genus of about 280 species, of which about 20 species are weeds $(1,21)$. The most common weed species are $H$. brevipes Poit., $H$. capitata Jacq., H. pectinata (L.) Poit. and H. suaveolens (L.) Poit. [now it is treated as Mesosphaerum suaveolens (L.) Kuntze (2)]. H. brevipes is an annual weed on cultivated lands or barren lands, including forest edges. It chiefly grows in the plantation of sugarcane, rice, banana, rubber cacao and mung bean and also in orchards and along roadsides. The species is native to Central and South America and it is said that it originated in Mexico (4). H. brevipes has been widely introduced across the SE Asia, where it has become naturalized in many parts (3-6). It has been listed as one of the chief weeds of Malaysia and common weed in Borneo, Philippines and Taiwan (5). Hyptis brevipes has now become invasive in Singapore, Thailand and Vietnam (7). It was reported as a destructive weed of moist and humid conditions, where it could pose a threat to crops and natural vegetation (8). It is assumed that $H$. brevipes might have been introduced into new areas as a contaminant of seed, in particular with rice (5).

In India, the species was first reported from Andaman and Nicobar Islands (South Andaman) in the year 1940 based on the specimens collected by G. King in 1890 (9). Further collection of the species was made again from South Andaman in 1973 by N. P. Balakrishnan. After the first report (9), the species was not again reported from any part of India till 2012. The sec- 
ond time this species was reported from Darjeeling Himalaya (10) of West Bengal. Recently, during the floristic survey of Dima Hasao District of Assam in NE India, we noticed this species growing luxuriantly in the sugarcane field near Dayanand Durg (Diyungbra) at $113 \mathrm{~m}$ altitude in moist conditions. The herbarium examination of this species at ASSAM further reveals that this species was also collected from Dampa Tiger Reserve of Mizoram along roadsides. The recent discovery of the species from NE India in 2017 indicates that the species has already invaded and naturalized in India. Since this alien weed also has invasive nature, there is an urgent need to control this species in the very beginning before it spreads rapidly and creates havoc in agriculture fields. Therefore, it is necessary to bring it to the notice of all people regarding the naturalization and invasive nature of the species, so that its spread can be controlled. In view of this, a detailed taxonomic account of the species and its distribution, phenology, uses and photographs are provided to confirm its identity and to take steps to control it from its further spread to some other regions.

\section{Materials and Methods}

During the field survey of the Dima Hasao district of Assam in November 2017, the plants were collected from the sugarcane fields near Dayanand Durg in the Diyungbra area. The photographs were taken, and GPS location data were recorded using the Garmin instrument (eTrex 10). For the preparation of herbarium specimens, standard techniques were followed $(11,12)$. The voucher specimens have been deposited at LWG for future record. The species was studied and identified under the stereo zoom dissecting microscope (Leica S8 APO). The description was prepared after examining several specimens to record the range of variations within the species. The protologue, photographs of type specimens, relevant literature $(9,10,13,14)$ and authentic specimens housed at CAL and ASSAM were critically examined to authenticate the identification of the species.

\section{Results and Discussion}

\section{Taxonomic treatment}

Hyptis brevipes Poit., Ann. Mus. Natl. Hist. Nat. Par. 7: 465. 1806; Hook. f., Fl. Brit. India 4: 630. 1885; Mukerjee, Rec. Bot. Surv. India 14 (1): 62. 1940; Paul \& Kumar, Indian J. Forest. 35 (1): 101, fig.1. 2012. (Figs. $1 \& 3$ ).

Annual, erect to prostrate herbs, sometimes twiners and grow upwards on other associated plants, 1-1.25 m high. Stem quadrangular, sparsely to densely appressed pilose. Leaves 3-8 × 1-2 cm, opposite, narrowly ovate to lanceolate or oblanceolate, narrowly cuneate at base, irregularly serrate and ciliate along margins, acute to acuminate at apex, punctate with dotted glands, hirsute on both surfaces; petiole 1-2 mm long, not very distinct. Inflorescence axillary, solitary, globose head; heads 5-10 mm across; peduncles 5-17 mm long, densely appressed pubescent. Involucral bracts $8-12$, at the base of each head, narrowly lanceolate to subulate, $3-8 \mathrm{~mm}$ long, entire and
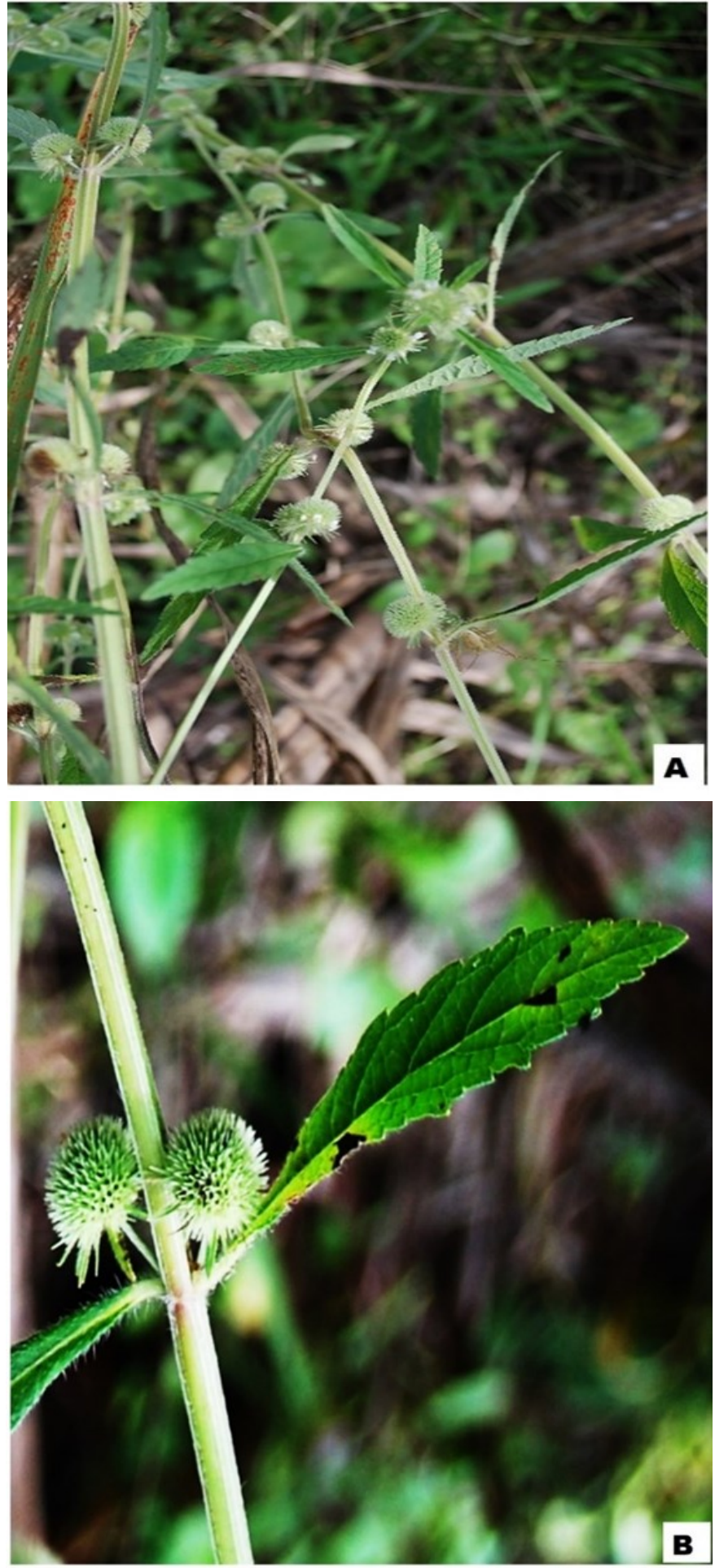

Fig. 1. Hyptis brevipes Poit. A. A portion of plant. B. Close-up of inflorescence and leaf.

ciliate along margins, spreading or reflexed, protruding head circumference. Calyx ca. $3 \mathrm{~mm}$ long, subcampanulate, 5-teethed, minutely hispid or pubescent outside, glabrous inside, tube ca. $1.5 \mathrm{~mm}$ long, teeth as long as tube, teeth narrowly triangular, mucronate at apex. Fruiting calyx dilated. Corolla white, ca. $4 \mathrm{~mm}$ long, bi-lipped, pubescent outside, Stamens 4, filaments free, slightly exerted. Ovary 4-partite; style shortly bifid at tip. Nutlets dark brown or black, ovoid, ca. $4.1 \times 0.5 \mathrm{~mm}$, smooth.

\section{Flowering \& Fruiting}

October-December. 
Habitat

This is a weed of crop fields and barren lands, including forest edges, moist and wet places.

\section{Distribution in India}

Andaman \& Nicobar Islands, W. Bengal, Mizoram, Assam (Fig. 2).

This has also been reported from Tripura (https:// efloraindia.bsi.gov.in/eFlora/speciesDesc_PCL.action? species_id=19910), but we have not observed any specimen from this region (FIG. 2).

\section{General Distribution}

Native to South and Central America, widely introduced across SE Asia where it has been naturalized as invasive in Indonesia, Malaysia, Philippines, Singapore, Taiwan, Thailand and Vietnam.

\section{Specimens examined}

INDIA, Andaman \& Nicobar Islands, South Andaman Island: 04.1890, King s. n. 353510 (CAL!); Port Mouat hill jungle, 21.11.1891, King's collector s. n. 353506 (CAL!); Dhani Khari

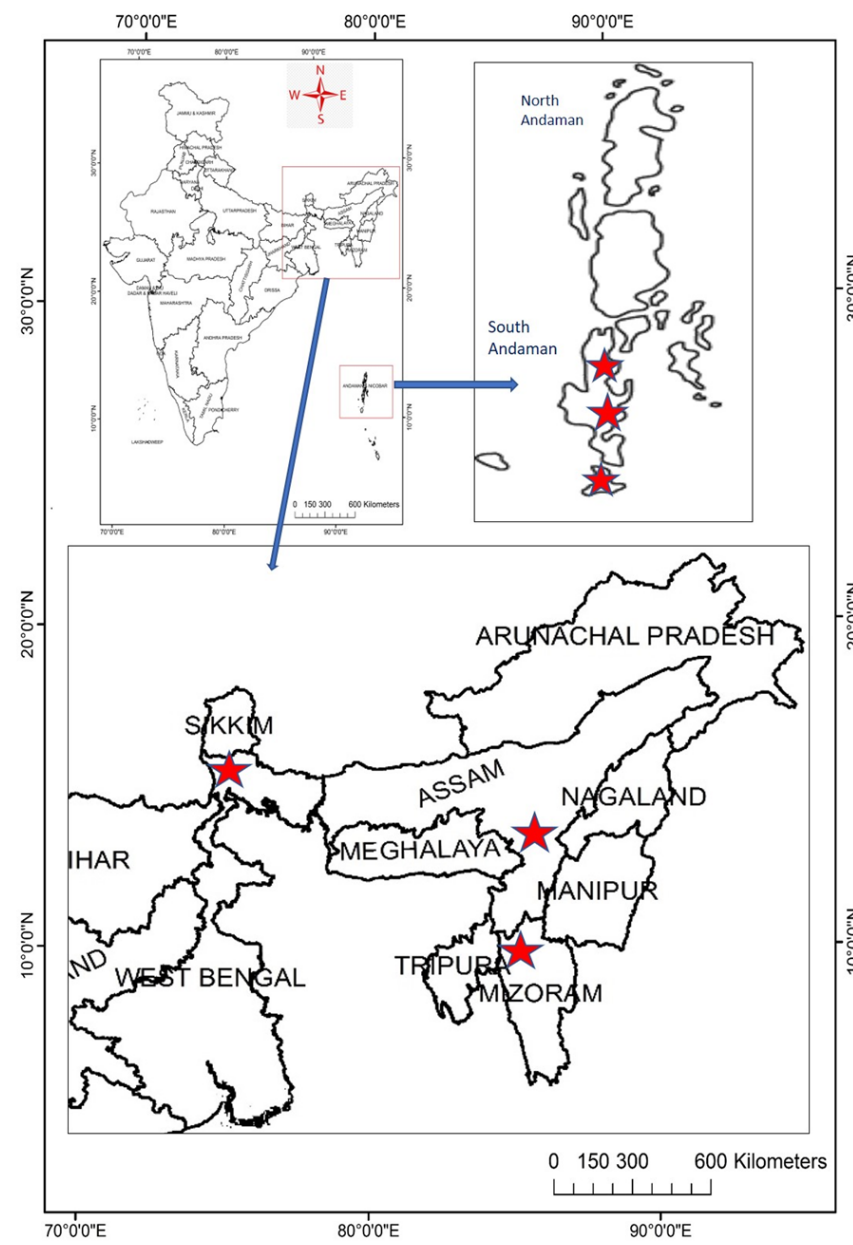

Fig. 2. Map showing the distribution of Hyptis brevipes Poit. in India.
Teirei roadside, 30.10. 2007, Sinha 117229 (ASSAM!). Assam: Dima Hasao, Dayanand durg. Diyungbra, 25 46' 849" N, 92 58' 373" E, 113 m, 02.11.2017, Chaudhary, Baleshwar, Verma \& Khan 312169 (LWG!).

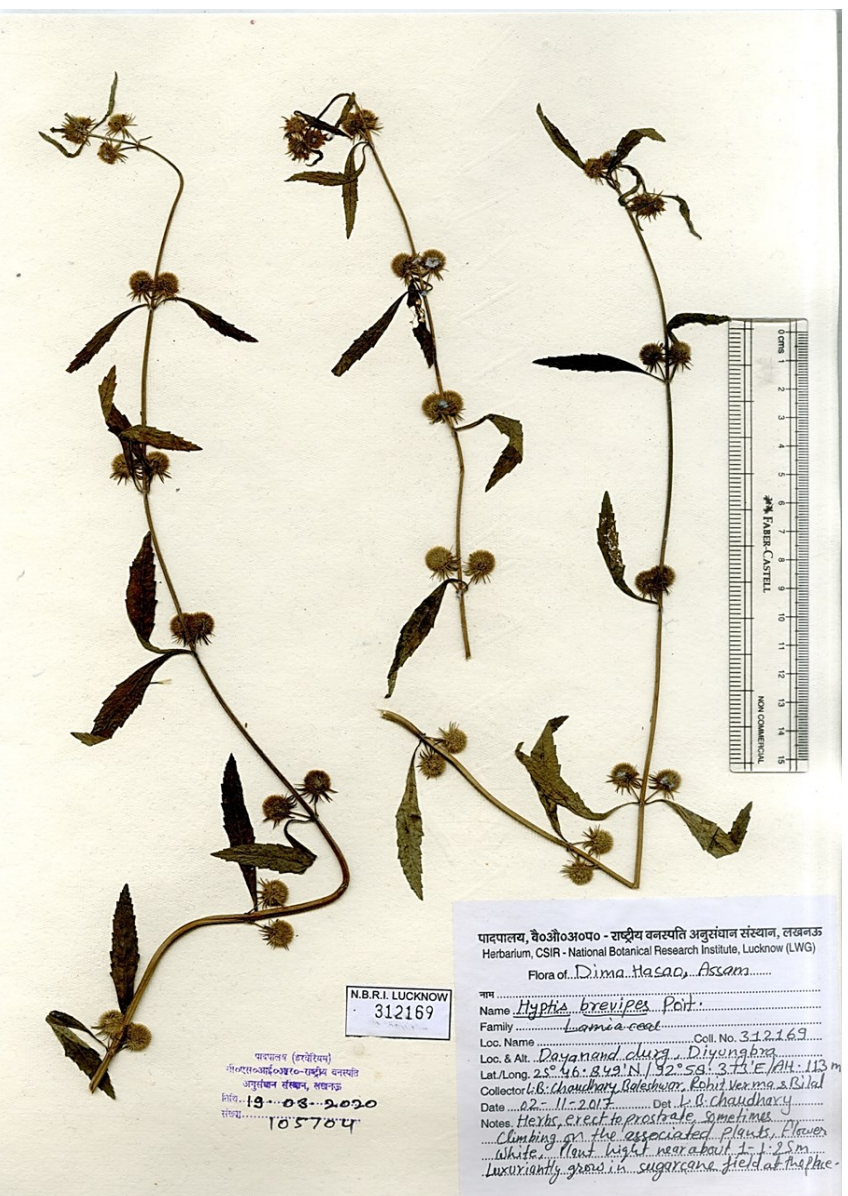

Fig. 3. Hyptis brevipes Poit. Image of the herbarium specimen.

\section{Notes}

Sometimes due to resemblances in general morphology $H$. brevipes is confused with the genus Leucas R. Br. However, among all the 4 species of Hyptis found in India (9), H. brevipes is more close to $H$. capitata from which it can be differentiated as follows:

1a. Leaves narrowly ovate to lanceolate or oblanceolate, 3$8 \times 1-2 \mathrm{~cm}$, about four times longer than width; peduncle $0.5-1.7 \mathrm{~cm}$ long; bracts distinctly protruding to the circumference of capitulum; calyx teeth more or less equal to tube and more narrowly pointed .H. brevipes

1b. Leaves broadly ovate, $11-14 \times 5-7 \mathrm{~cm}$, about two times longer than width; peduncle 4-5 cm long; bracts more or less equal to the circumference of capitulum; calyx teeth shorter than tube and acute to acuminate

\section{H. capitata}

Uses

hill jungle, 19.11.1892, King's collector s. n. 353509 (CAL!); H. brevipes is considered a good forage in Malaysia (15). It Cadellganj Creek, 16.09.1893, King's collector s. $n$. 353507 has strong antimicrobial or insecticidal properties (16). Its (CAL!); Between Ali Masjid \& Bumlitan hill jungle, 21. extract inhibits the growth of larvae of the cotton leaf10.1893, King's collector s. n. 353508 (CAL!); Maymyo, worm Spodoptera littoralis (17, 18). It is also used as a tea 14.11.1993, Balakrishnan 1379 (CAL!). West Bengal: Darjee- to treat colds, fever, headache and gout. The oil of $H$. breviling district, Mahananda WLS, Sukna, 23.11. 2006, Paul \& pes has been reported to be used in folk medicines for the Kumar 41223, 41297 (CAL!). Mizoram: Dampa Tiger Reserve, treatment of asthma and malaria, conservation of cereals 
and repel mosquitoes (16). The juice of leaf is squeezed and 3 . applied on fresh wounds (19). Dried leaves may be used as incense and its strong aroma is thought to be good for warding off evil spirits (19).

\section{Conclusion}

The invasive alien plant species are a serious threat to local biodiversity throughout the world (20). H. brevipes is a native weed of South and Central America and has been naturalized in many parts of the SE Asia. It is also regarded as a destructive weed wherever it has invaded and naturalized. In the present study it has also been noticed that the weed has recently naturalized in different parts of NE India and is spreading rapidly especially in agriculture fields. Since this is fast growing and invasive, its spread must be controlled from the very beginning before it creates havoc in agriculture fields and harms local flora by replacing and dominating them. The species can be controlled in the wild by weeding out its plants in young stages or before the development of flowers and fruits on the plants. Therefore, it is important to have more information on it and bring it to the notice to people, so that its invasion can be stopped well in advance.

\section{Acknowledgements}

The authors are thankful to the Director, CSIR-National Botanical Research Institute, Lucknow for providing facilities. Assam State Biodiversity Board, Guwahati and MoEF \& CC, New Delhi (NMHS-2017/LG-01/475) are duly acknowledged for financial assistance. Thanks, are also due to curators/incharge of herbaria mentioned in work for granting permission to study the herbarium specimens and downloading images of specimens/type specimens from their webpage. We are also grateful to all staff of forest departments of Dima Hasao district for their constant help provided during field work.

\section{Authors contributions}

RKV, BAK, BM and LBC collected plant materials; RKV, WVW and LBC identified species; LBC and RKV prepared the manuscript; SKB \& ST helped in the preparation of the manuscript.

\section{Compliance with ethical standards}

Conflict of interest: Authors do not have any conflict of interests to declare.

Ethical issues: None.

\section{References}

1. Randall RP. A global compendium of weeds. $3^{\text {rd }}$ ed. Perth, Australia; 2017.

2. POWO (Plants of the World Online). Royal Botanic Gardens, Kew, England. http://powo.science.kew.org/taxon/urn:lsid:ipni.org:names:448418-1
Reed CF. Economically Important Foreign Weeds: Potential Problems in the United States. Agricultural Research Service, Animal and Plant Health Inspection Service. U. S. Dept. of Agriculture, Washington, DC. 1977; 746.

4. Kostermans AJGH, Wirjahardja S, Dekker RJ. The weeds: description, ecology and control. In: Soerjani M, Kostermans AJGH, Tjitrosoepomo G (Editors.). Weeds of Rice in Indonesia. Balai Pustaka. Jakarta, Indonesia; 1987.

5. Holm LG, Pancho JV, Herberger JP, Plucknett DL. A Geographical Atlas of World Weeds. Wiley and Sons. New York; 1979.

6. Waterhouse DF. The Major Arthropod Pests and Weeds of Agriculture in Southeast Asia. Australian Centre for International Agricultural Research, Canberra; 1993.

7. Pier. Pacific Islands Ecosystems at Risk. Honolulu, USA: HEAR, University of Hawaii; 2017. http://www.hear.org/pier/index.htm

8. Lorenzi H. Plantas Daninhas do Brasil:Terrestres, aquaticas, parasitas, toxicas e medicinais. Nova Odessa, Sao Paulo; 1982.

9. Mukerjee SK. A Revision of the Labiatae of the Indian Empire. Rec. Bot. Sur. India.1940;14(1):11-228.

10. Paul TK, Kumar A. Extended distribution of Hyptis brevipes Poit. in India. Indian J For. 2012;35:101-02.

11. Lawrence GHM. Taxonomy of Vascular Plants. Oxford IBH publishing Co. Pvt. Ltd., New Delhi; 1951. https:// onlinelibrary.wiley.com/doi/10.1002/sce.3730360536

12. Jain SK, Rao RR. A handbook of field and herbarium methods. Today \& Tomorrow's Printers and Publishers. New Delhi; 1977.

13. Hooker JD. The Flora of British India, vol. 4. L. Reeve \& Co., London;1885.

14. Datar MN, Lakshminarasimhan P, Rao PSN. Hyptis capitata Jacq. (Lamiaceae) - A new record for Northern Western Ghats. Indian J. For. 2007;30 (3):355-56.

15. Wahab HA. Forages in Oil Palm and Rubber Plantations in Malaysia. (7th Meeting of the Regional Working Group on Grazing and Feed Resources 'Forage Development in Southeast Asia: Strategies and Impacts' July 2001), Manado, Indonesia; 2001.

16. Bhuiyan MNI, Begum J, Nandi NC. Chemical component studies on the leaf and inflorescence essential oil of Hyptis brevipes Poit. J Med Plant Res. 2010;4(20):2128-31.http:// www.academicjournals.org/JMPR/PDF/pdf2010/180ct/ Bhuiyan\%20et\%20al.pdf

17. Sakr HH, Roshdy SH, El-Seedi HR. Hyptis brevipes (Lamiaceae) extracts strongly inhibit the growth and development of Spodoptera littoralis (Boisd.) larvae (Lepidoptera: Noctuidae). J Appl Pharm Sci. 2013;3 (10): 83-88. http://www.japsonline.com/ admin/php/uploads/1081_pdf.pdf

18. Sakr HH, Roshdy SH. Effect of Hyptis brevipes (Lamiaceae) Methanol Extract on Spodoptera littoralis (Lepidoptera: Noctuidae) Larvae. Res J Pharm Biol Chem Sci. 2015;6 (6):651-58.

19. Jamaica Observer. Get a 'woman piaba' bath to relieve stress; 2017. http://www.jamaicaobserver.com/westernnews/Get-a'woman-piaba'-bath-to-relieve-stress

20. Walther GR, Roques A, Hulme PE, Sykes MT, Pysek P, Kuhn I, et. al. Alien species in a warmer world: risks and opportunities. Trends in Ecology and Evolution 24;2009;24:686-93.

21. Suddee S, Paton AJ, Parnell JA. A taxonomic revision of tribe Ocimeae Dumort. (Lamiaceae) in Continental South East Asia I. Introduction, Hyptidinae \& Hanceolinae. Kew Bull. 2004; 59 (3):337-78. 